\title{
The Crisis: The Relentless Resulting of an Explosive Cycle
}

\author{
Xavier Brédart ${ }^{1}$ \\ ${ }^{1}$ Accounting and Management Department, Warocqué School of Business and Economics, University of Mons, Mons, \\ Belgium \\ Correspondence: Xavier Brédart, PhD \& Teaching Assistant, Accounting and Management Department, Warocqué \\ School of Business and Economics, University of Mons, 20, place du Parc, 7000 Mons, Belgium. Tel: 32-65-373-213. \\ E-mail: xavier.bredart@umons.ac.be
}

Received: April 7, 2014

doi:10.5430/ijfr.v5n3p68

\author{
Accepted: April 23, 2014 \\ Online Published: June 1, 2014 \\ URL: http://dx.doi.org/10.5430/ijfr.v5n3p68
}

\begin{abstract}
The aim of this paper is to analyze the causes that led to the subprime crisis. A general analytical framework on the issue of crises is used. On one hand, we base our analysis on the theory of financial cycles and, secondly, on the precepts of political economy. First, it is clear from our analysis of cycles that the optimistic and "sheep-like" behavior on the financial market contributes to the formation of speculative bubbles. Second, although the Federal Reserve (FED) can be singled out as responsible for the subprime crisis, economists have not been able to mobilize existing and well known theoretical economic precepts to prevent this turmoil.
\end{abstract}

Keywords: crisis, financial cycle, political economy, speculative bubble

\section{Introduction}

As per Claessens et al. (2010), similarities can be established between the different crisis episodes. However, Hautcoeur (2011) argues that financial crises all have their own specificities. The subprime crisis, considered by experts to be the worst since the thirties, is mainly linked to the American mortgages policy (Myftari and Rosi, 2010). According to the contemporary cycle theory, the origin of the crisis lies in the manipulation of key interest rates by the Federal Reserve (Salin, 2011). In 2000, when the growth rate of the U.S. economy began to decline, the Fed decided to lower its key interest rate until 2004. This artificially low rate had the expected effect; growth came back. However, in late 2004, following the threat of inflation induced by rising commodity prices, the Fed raised its rate. This caused a decline in growth rate to finally achieve a recession in the United States in 2009. Note that the rate changes made were artificial because they did not reflect changes in the propensity to save of U.S. households (Facchini, 2010). Nevertheless, as a consequence, saving and investment were disconnected; this encouraged American households to borrow. This model was therefore based only on the assumption of a constant growth, which was inherently unsustainable and begat ultimately a speculative bubble.

If the Fed can be held responsible for the improper management of interest rate, other actors as economists, may also be implicated (Taleb, 2010). Although some of them had issued warnings between 2000 and 2006 (Krugman, 2000; Krugman, 2004; Aglietta, 2001; Stiglitz, 2003; Shiller, 2005. Bourguinat, 2006), their message seems to have been drowned in a optimism maintained by the speculative opportunities. Professional economists were particularly criticized for their dogmatic assumptions relative to the shareholder model that are the residual debt (Jensen, 2000) and market efficiency (Fama, 1970). It must be recognized that the reference to the "mainstream" has greatly influenced the acceptance of publications in academic journals. The shareholder governance theory is so present in the academic literature that despite recent events, we still cannot say that their questioning is fully recognized (Rainelli -Le Montagner, 2009). The precepts of political economy, which had been emphasized after the 1929 crisis, also seem to have been overshadowed by many economists. Other criticisms may be made to economists; for instance, their blind faith in financial innovation to stimulate the economy and too much indulgence towards the financial community (De Boissieu and Jacquillat, 2010). It should also be noted that the rapid changes in the financial markets has surprised some renowned economists such as Alan Greenspan, chairman of the U.S. Federal Reserve from 1987 to 2006. The latter, blinded for several decades by Friedman's theories (1970), will make his "mea culpa" in October 2008.

The objective of this paper is to analyze the causes that led to the subprime crisis. To this end, we base on a general analytical framework on the issue of crises, resting one hand on the theory of financial cycles and, secondly, on the 
precepts of political economy. To this end, sections 2 and 3 are respectively related to, financial cycles and to fundamental economic theories. We conclude this article by identifying the various weaknesses inherent in the capitalist system of the early 21 st century.

\section{From Financial Cycles to Speculative Bubbles}

The crises usually find their origin in the formation and bursting of speculative bubbles. According to historian Charles Kindleberger (1987), a bubble is defined as follows: "A sharp increase in the price of an asset or a range of assets in a continuous process where the initial rise generates expectations for speculators interested in profits from the sale rather than by profits generated by the asset itself. The increase is usually followed by a reversal of expectations and a sharp decline in prices often leading to a financial crisis."

The first bubble of economic history is known as the "crisis of the tulip". The "tulipomania" has occurred in the mid-17th century in the Northern United Provinces. Between November 1636 and February 1637, the exchange price of the tulip bulb was multiplied by twenty (Thompson, 2007). This disproportionate increase in the exchange value will be followed by the collapse of the price of the tulip bulb, which in May 1637, returns to its level of November 1636, resulting in the destruction of the wealth of thousands of families. Throughout history, many similar episodes, marked by the swelling and then exploding bubbles, happened. For instance, in 1720, the French market collapsed because of the rise then of the fall of the stock prices of the Mississippi Company. During the 19th century, the development of railways also caused a surge in stock prices before reaching a sharp reversal. A similar phenomenon was recorded in October 1929 in Wall Street. More recently, the momentum of the capital works program aimed at developing information technology initiated under Reagan and dubbed "Star Wars", allowed the United States to know, a period of prosperity during the nineties marked by the surge in technology stocks. While the benefits of the new economy seem sustainable, in March 2000, stock prices of companies in TMT (technology, media and telecommunications) have dropped abruptly. The latest bubble is the one of the housing in the United-States that led to the subprime crisis. Aiming to support U.S. demand, the conditions of access to credit have been eased, resulting in an important increase in property prices. The securitized assets reflecting mortgages have suddenly raised doubts and caused the downturn in property prices. This caused the bankruptcy of many American households. From these examples, it appears that the process of inflation/deflation of bubbles seems to repeat itself repeatedly in the capitalist context.

From his analysis of financial crises, Kindleberger (1996) highlighted the recurrence of five phases inherent to financial cycles. The first one is the growth and usually follows a period of reduced economic activity. During this phase, the growth is fueled by real investment whose is funded by a credit that remains in line with the incomes. This growth is then considered as "healthy" but is already creating optimistic behavior pushing up the price of some assets to rise. The second phase of the cycle is that of euphoria in which large increases in asset prices are observed; these are accompanied by a general credit boom that is less and less in line with income growth. This phase is characterized by over-indebtedness an underestimation of risk. The next phase is characterized by the paroxysm and the reversal. The debt leverage is used at its peak. The system still works thanks to the speculative rise of the collateral values. At an unpredictable time, doubts regarding the valuation of these values appear, and prices fall. During the reflux stage, which is characterized by the introduction of pessimism, on the one hand, indebted agents are "obsessed" by seeking liquidity and, secondly, the liquidity providers are hesitant to lend because their risk aversion has increased. Finally, comes the phase of balance sheet restructuring. Many entities sell their assets in panic, resulting in a fall in the prices.

The "sheep-like" behavior that is characteristic of the phase of euphoria may appear irrational because prices cannot rise without limit (Tirole, 1982). In addition, as per a study by Shiller (1989) conducted in the U.S. market before the krack of October 1987, most economic agents are aware of acting on a speculative market but do not feel threatened because they think they (and not the other agents) will come out in time. All the speculative agents therefore make the same bet that they will benefit from the bubble and that they will sell their assets at the right time. This bet is based on their ability to anticipate "the average opinion" regarding the prices of the assets in the near future (Keynes, 1936); this implies the use of self-referential and mimicry behaviors rather than the use of a rational judgment. Although there are statistical tests to detect bubbles (West, 1987; Levin and Wright, 1997), it remains difficult to determine the moment of their explosion (Cutler et al., 1989).

So, the phenomena of swelling/explosion of bubbles makes part of the financial system and is endogenous to the capitalist system. According to Schumpeter (1943), crises are necessary in the capitalist system (Schumpeter, 1911). As per his cyclical analysis in four phases (recovery, prosperity, recession and depression), Schumpeter considers the crises as a necessary phenomenon's. He names this the "creative destruction". At the origin of these cycles, there is invariably an innovation that is particularly attractive in terms of profit. Irresistibly attracted by the hopes of gains, new companies emerge and borrow a lot in order to make profits thanks to the innovation as soon as possible. In doing so, 
they induce a phase of expansion, boosted by the speculation. The expansion continues until some revaluations of profit outlook cause a reversal of the economic activity (Boyer, 2010).

In the vein of Schumpeter, Sauvy (1980) shows that the disorder caused by a major discovery should not, however, lead to renounce to innovation because, in a second time, the crisis allows to purge the system and prepares the ground for a new wave of innovations and therefore for a new growth. Different types of cycles have been developed. The Russian statistician Kondratieff (1926) highlights long cycles of 40-60 years. Schumpeter notes that these periods correspond to major technological developments that are steam engine, railway, electricity, car, and finally the new technologies. This "sinisoidal" representation (see Figure 1) of capitalism illustrates the idea that history is made of bullish and bearish periods and that innovation is the cause of crises.

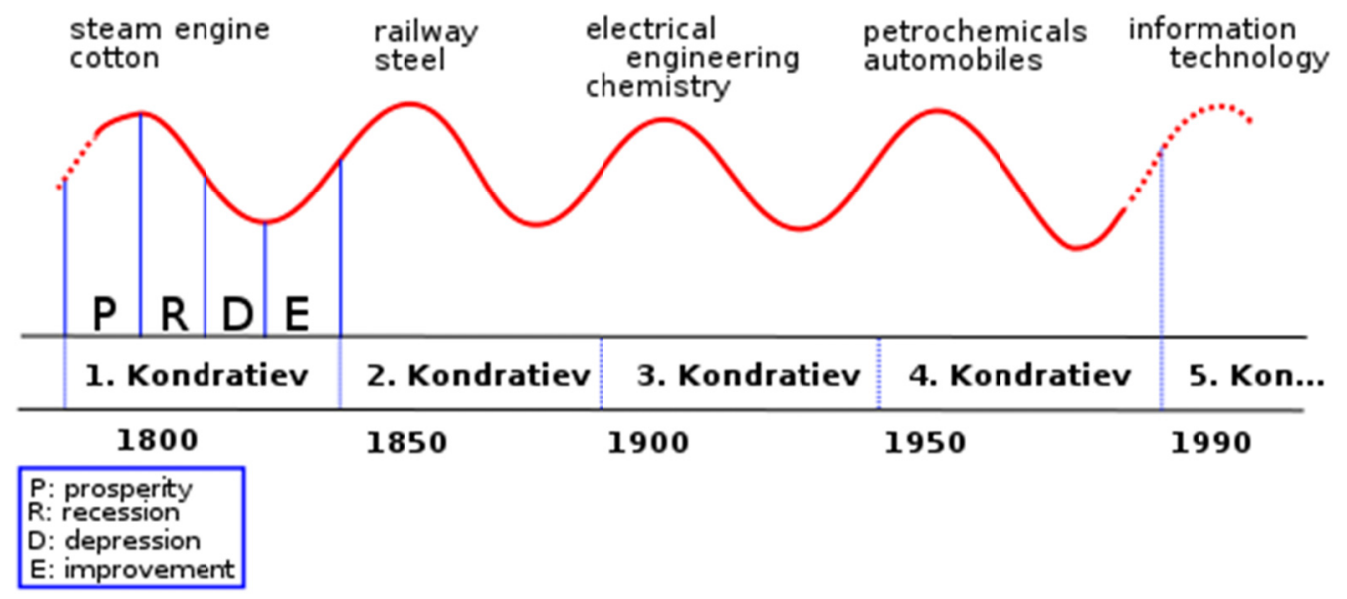

Figure 1. Kondratieff cycles and technological innovations

Source: Tonglet, B. (2003). La déflation: Qu'en dites-vous Nikolaï Kondratieff?. Paris, L'Harmattan.

When the turning point is reached, companies are left with excess inventory, which tends to lower prices. Some heavily exposed banks and firms must declare bankruptcy. The situation ends up being stabilized, optimism and investment are back and a new cycle begins. During the technological euphoria of the late nineties, some have announced the "end of cycle"; in other words, the advent of perpetual growth. This belief was quickly denied by the successive explosions of the Internet and of the housing bubbles.

\section{The Precepts of Political Economy}

The violence and the extent of the subprime crisis have forced many analysts to reconsider the importance of basic economic theories. The process of financial deregulation, which has been accelerated in the nineties, has conferred to the finance an increasingly important role in the economy (Boyer, 2010). The Finance now dominates the economy and imposes its torrid pace. Financial innovations based on cheap credit have helped to consolidate the financial supremacy that is more and more disconnected from the rest of the economy. At the origin of the subprime crisis, there is the phenomenon of deregulation of finance initiated in the 80s. This phenomenon was supported by the dominant ideology. That said, the failure of the "invisible hand" leads many experts to reconsider the Keynesian assumptions about crises.

Lessons learned from past crises and from analyzes of economists such as Keynes, Minsky, Schumpeter, or Fisher seem to have been overshadowed by the mirage of a relentless uptrend. Keynes (1936) contends that: "we cannot say that speculation always prevails over the company. However, the risk of a predominance of speculation tends to grow as the organization of financial markets increases". In other words, a strong market development and an intense sophistication of financial instruments lead to encourage speculation. The speculative appeal has the effect of encouraging excessive debt. As per Fisher (1933), "Easy money is the major cause of indebtedness. When an investor believes he can make more than $10 \%$ profit per annum by borrowing at $6 \%$, he will be tempted to borrow and invest or speculate with borrowed money". Minsky (1992) develops the "financial instability" hypothesis. The first step of his theory is to provide a typology of balance sheets into three categories:

- Prudent structures within which the incomes of the investment do cover all financial commitments;

- Speculative structures in which profits do cover the payments of interests but not the payments in capital; 
- "Ponzy" structures in which profits do not cover the payments at all.

With this typology, Minsky can classifying economies according to the funding structure of entities. If the proportion of speculative and Ponzy structures is high, then, the economy is weak and vice versa. He then remarks that "during prolonged periods of prosperity, capitalist economies evolve from one financial structure dominated by prudent units towards a structure in which speculative and Ponzi units are important" (Minsky, 1992). Echoing the work of Schumpeter, he postulates the endogenous and cyclical nature of crises. He says that crises are caused by the financial fragility that occurs during upswings in the economy. When the financial fragility reaches a certain level, the interest rate is necessarily student (Nasica, 1997) and the most fragile entities disappear. Other dependent entities then fall; this initiates a spiral. According to Minsky, the pursuits of profit and of innovation are incentives to speculation. This must be controlled through public interventions tailored aiming to discipline the behavior of agents and thus to maintain a degree of financial robustness.

Minsky's recommendations were not followed. For the Internet crisis, investors had anticipated high returns thanks to the advent of new technologies. In the subprime crisis, an infinite rise of mortgage prices had been assumed and the enrichment made possible by the financial omnipotence seems to have been pushed to the extreme. In either case, the state intervention seems inevitable. Finally, the pursuit of profit disconnected from reality and a severe lack of supervision have contributed to the emergence of the subprime crisis.

Boyer (2010) summarizes the different steps of a financial cycle in which each loop ends with the intervention of public authorities in order to restore confidence and to introduce new rules to prevent the occurrence of new episodes of crisis. Once the crisis is over, the good intentions are quickly replaced by the opportunism and any significant innovation is likely to initiate a new cycle. Also, many experts predict the next speculative episode in the renewable energy sector.

\section{Conclusion}

This article, that focusses on the subprime crisis, allowed us to identify various weaknesses inherent in the capitalist system of the early 21 st century among which the cyclic and endogenous characters of crises. The American system, characterized by cheap credit and that has faith in self-regulated markets, seems to have staked all his hopes in maintaining an upward trend the economy. Nevertheless, the recent economic crises have contradicted this hope.

The seizure of power by the financial elite and the development of complex and opaque financial instruments have led to an acute informational asymmetry. As a consequence, investors have been misled about the risks of securitized assets and the market value of these assets was deviated from their real value. Consequently, decisions to buy or sell assets were heavily based on a mimetic process rather than on an estimate knowingly. In other words, prices were determined by the speculation. Lenders and borrowers have indeed been encouraged to participate in a game whose rules have been enacted by the financial sector. The securitization mechanisms have so, "muddied the waters" and have also disconnected prices and the real value of the assets. As a consequence, the market turned into a speculative casino that is self-persuaded of its heresies of infinite growth. In mid-2007, the housing bubble exploded. One year later, the financial sector collapsed and, finally, the rest of the economy, involving a generalized recession phenomenon.

In terms of regulation, a repositioning of the financial sector in the capitalist economic landscape seems necessary in order to limit the incentives for systematic use of "speculative strategy". This strategy is indeed interesting during the early phases of financial cycles but it inexorably lead to a weakening of the economy.

Finally, note that the crises are endogenous and cyclic and therefore make an integral part of the capitalist system. Accordingly, the use of regulations can help avoid falling into the traps of the past but will not eradicate the crisis episodes because, once established, the regulation will inevitably be bypassed by one or more of the economic actors (Shachmurove, 2010).

\section{References}

Aglietta, M. (2001). Macroéconomie financière : crises financières et régulations monétaires. Paris, La Découverte.

Bourguinat, H. (2006). Les intégrismes économiques: essai sur la nouvelle donne planétaire. Paris, Dalloz-Sirey.

Boyer, R. (2010). L'économie en crise: le prix de l'oubli de l'économie politique. L'économie politique, 47(3), 46-89. http://dx.doi.org/10.3917/leco.047.0046

Claessens, S., Kose, M.A., \& Terrones, M.E. (2010). The global financial crisis: how similar? How different? How costly?. Journal of Asian Economics, 21, 247-264. http://dx.doi.org/10.1016/j.asieco.2010.02.002

Cutler, D. M., Poterba, J. M., \& Summers, L. H. (1989). What moves stock prices?. Journal of portfolio management, 
15(3), 4-12. http://dx.doi.org/10.3905/jpm.1989.409212

De Boissieu, C., \& Jacquillat, B. (2010). A quoi servent les économistes?. Paris, Presses universitaires de France.

Facchini, F. (2010). 2007: une crise systémique?. Revue d'économie financière, 97(2), 155-183. http://dx.doi.org/10.3406/ecofi.2010.5397

Fama, E. (1970). Efficient capital market: a review of theory and empirical work. The Journal of Finance, 25(2), 383-417. http://dx.doi.org/10.2307/2325486

Fisher, I. (1933). La théorie des grandes dépressions par la dette et la déflation. Revue Française D'économie, 3(3), 159-182. http://dx.doi.org/10.3406/rfeco.1988.1188

Friedman, M. (1970). The social responsibility of business is to increase its profits. New York times magazine.

Hautcoeur, P.-C. (2011). Chaque grande crise est différente. Economie et Statistique, 1(4), 438-440.

Jensen, M. (2000). A Theory of the firm: governance, residual claims, and organizational forms. Cambridge, Harvard university press.

Keynes, J. M. (1936). Théorie générale de l'emploi, de l'intérêt et de la monnaie. Paris, Payot.

Kindleberger, C. (1987). International capital movements. New York, Cambridge university press.

Kindleberger, C. (1996). Manias, panics and crashes: a history of financial crisis. London, Wiley.

Kondratieff, N.D. (1926). Les vagues longues de la conjoncture. Revue française d'économie, 2(4), 168-188. http://dx.doi.org/10.3406/rfeco.1987.1162

Krugman, P. (2000). Pourquoi les crises reviennent toujours. Paris, Seuil.

Krugman, P. (2004). L'Amérique dérape. Paris, Flammarion.

Levin, E., \& Wright, R. (1997). The impact of speculation on house prices in the United Kingdom. Economic modelling, 14(4), 567-85. http://dx.doi.org/10.1016/S0264-9993(97)00008-4

Minsky, H. (1992). The financial instability hypothesis. The Levy economics institute working paper collection.

Myftari, E., \& Rossi, S. (2010). Prix des actifs et politique monétaire enjeux et perspectives après la crise financière de 2007-2009. L'actualité économique, 86(3), 355-383. http://dx.doi.org/10.7202/1003527ar

Nasica, E. (1997). Comportements bancaires et fluctuations économiques : l'apport fondamental d'H. Minsky à la théorie des cycles endogènes et financiers. Revue d'économie politique, 107(6), 853-873.

Rainelli-Le Montagner, H. (2009). La nouvelle finance est-elle une finance critique. Québec, Presses Universitaires de Laval.

Salin. (2011). De la crise financière à la crise de la dette et de l'euro. L'Actualité économique, 87(4), 503-518. http://dx.doi.org/10.7202/1012569ar

Sauvy, A. (1980). La machine et le chômage. Paris, Dunod, p319.

Schumpeter, J. (1943). Capitalisme, socialisme et démocratie. Paris, Payot.

Shiller, R. J. (1989). Market volatility. Cambridge, MIT Press.

Shiller, R. J. (2005). Irrational exuberance. Princeton, Princeton university press.

Stiglitz, J. (2003). The roaring nineties. Paris, Fayard.

Taleb, N. N. (2010). Why did the crisis of 2008 happen?. SSRN working paper. Retrieved from http://ssrn.com/abstract $=1666042$

Thompson, E. A. (2007). The tulipmania: fact or artifact?. Public Choice, 130(1), 99-114. http://dx.doi.org/10.1007/s11127-006-9074-4

Tirole, J. (1982). On the possibility of speculation under rational expectations. Econometrica, 50(5), 1163-1182. http://dx.doi.org/10.2307/1911868

Tonglet, B. (2003). La déflation: Qu'en dites-vous Nikolaï Kondratieff?. Paris, L'Harmattan.

West, K. D. (1987). A specification test for speculative bubbles. The quarterly journal of economics, 102(3), 553-580. http://dx.doi.org/10.2307/1884217 